\title{
PENGELOLAAN PROGRAM KB NASIONAL DI DKI JAKARTA TAHUN 2014
}

\author{
Menara Simanjuntak; Haryadi Sarjono; Iwan Zulkifli \\ Management Department, School of Business Management, BINUS University \\ Jln. K.H. Syahdan No.9, Palmerah, Jakarta Barat 11480 \\ Menara0110@yahoo.com; haryadi_s@binus.edu
}

\begin{abstract}
Research of the National Family Planning Program Management in Jakarta is the follow-up study that analyzes the role of the relationship manager / executive of Family Planning, the availability of caunsellor and cadres as well as the readiness of Family Planning services to the dependent variable. Dependet variable is the interaction of the managers/implementers Family Planning to the achievement of family planning program in Jakarta. The purpose of this study was to obtain analytical results in the relationship of important variables in the management of family planning programs in Jakarta as a basis for priority activities proposed in the action plan of the family planning program in Jakarta. This study uses quantitative analysis with the technic of achieving sample by stratified random sampling, with a total sample of 198 respondents from the Provincial, Municipal and District Level. After the research team analyzes the results of the regression relationships of variables to provide conclusions and recommendations as an attempt to formulate strategic activities in the implementation of the National Family Planning Program in Jakarta. It can be concluded that there is influence and significant simultaneous relationship between the role of managing/implementing family planning programs and the readiness of Family Planning services in their effort to the success of family planning programs in Jakarta. Based on the results of quantitative data processing of the regression equation with the interpretation output LISREL with the value of $R$ square of 0.493 or 49.3 percent.
\end{abstract}

Keywords: role manager, facility services, achievement FP program, managerial interactions, revitalization FP program

\begin{abstract}
ABSTRAK
Penelitian Pengelolaan Program Keluarga Berencana Nasional di DKI Jakarta sebesar studi lanjutan yang menganalisis hubungan peran pengelola/pelaksana Keluarga Berencana, ketersediaan penyuluh dan kader serta kesiapan sarana pelayanan Keluarga Berencana terhadap variable dependen. Variabel dependen sebesar interaksi para pengelola/pelaksana Keluarga Berencana terhadap pencapaian program Keluarga Berencana di DKI Jakarta. Tujuan penelitian ini sebesar untuk memperoleh hasil analisis mengenai hubungan antar variable penting dalam pengelolaan program KB di DKI Jakarta untuk dijadikan dasar dalam mengusulkan kegiatan prioritas dalam rencana kegiatan program KB di DKI Jakarta. Penelitian ini menggunakan metode analisis kuantitatif dengan teknik pengambilan sampel stratified random sampling, dengan jumlah sampel sebanyak 198 responden dari Tingkat Provinsi,Tingkat Kotamadya dan Tingkat Kecamatan. Setelah Tim Peneliti menganalisis hasil regresi hubungan antar variable untuk memberikan kesimpulan dan rekomendasi bagi upaya untuk merumuskan kegiatan strategis dalam pelaksanaan Program Keluarga Berencana Nasional di DKI Jakarta. Dapat disimpulkan bahwa ada pengaruh dan hubungan secara simultan yang signifikan antara peran pengelola/pelaksana program KB dengan kesiapan sarana pelayanan KB dalam mencapai keberhasilan program Keluarga Berencana di DKI Jakarta. Berdasarkan hasil pengolahan data kuantitatif persamaan regresi dengan interpretasi output LISREL dengan nilai $R$ square sebesar 0.493 atau 49,3 persen.
\end{abstract}

Kata kunci: peran pengelola, sarana pelayanan, pencapaian program KB, interaksi pengelola, revitalisasi program KB 


\section{PENDAHULUAN}

Masalah yang dihadapi dalam pelaksanaan program Keluarga Berencana (KB) di era otonomi daerah ini sebesar jumlah penyuluh KB yang menurun lebih dari separuh jumlah total penyuluh KB di seluruh Indonesia. Data tahun 1997 menunjukkan jumlah sekitar 50.000 orang penyuluh KB sementara pada tahun 2010 sekitar 21.000 orang. Sebagian besar penyuluh KB telah pindah tugas ke instansi lain atau purna tugas dan hampir selama 12 tahun tidak ada penyuluh KB baru untuk menggantikan mereka yang pindah maupun yang telah purna tugas. Contoh kasus di DKI Jakarta, pada tahun 1997 jumlah PKB mencapai 602 orang dan pada tahun 2010 berkurang menjadi 452 orang karena pindah tugas dan pensiun.

Keadaan ini berimbas pada kinerja program KB Nasional yang semakin sulit menambah proporsi jumlah peserta KB aktif pada Pasangan Usia Subur (PUS) Program KB nasional ini dilakukan untuk menurunkan laju pertumbuhan penduduk alami sampai mendekati 1 persen. Namun kenyataannya berdasarkan Sensus Penduduk 2010 laju pertumbuhan penduduk (LPP) naik dari 1,20 persen menjadi 1,39 persen di DKI Jakarta dan dari 1,43 menjadi 1,49 persen di Indonesia dalam kurun tahun 2000-2010. Selain itu, berdasarkan International Demography and Health Survey tahun 2012 diperoleh hasil yang menunjukkan penurunan peserta KB aktif dari 61 persen menjadi 57 persen dari jumlah PUS di DKI Jakarta. Survei juga menunjukkan bahwa Angka Kelahiran Total Rata-Rata Wanita Kawin (Total Fertility Rate/TFR) naik dari 2.1 menjadi 2,3, dan indikasi ini menunjukkan bahwa angka kelahiran meningkat.

\section{Urgensi Masalah}

Masih cukup banyak orang mengingat tentang kesuksesan Indonesia pada era tahun 80-90-an dibidang KB dan Pertanian. Dibidang Keluarga Berencana, Indonesia berhasil menurunkan Angka Kelahiran Total Rata-rata per Wanita Kawin dari 5,6 anak menjadi 3,2 anak per wanita kawin, yang artinya rata-rata seorang ibu memiliki sekitar 3 anak dan khusus di DKI Jakarta, Jogyakarta dan Bali mencapai sekitar 2 anak. Kemudian setelah hampir 10 tahun sejak reformasi pemerintahan yang ditandai dengan desentralisasi kewenangan yang lebih luas dalam sebuah otonomi daerah tidak mempengaruhi upaya penurunan Angka Kelahiran di DKI Jakarta. Berdasarkan Sensus Penduduk tahun 2010 (SP-2010), laju pertumbuhan penduduk alami secara nasional mengalami kenaikan dari sekitar 1,43 persen pada tahun 1990-2000, menjadi 1,49 persen tahun 2000-2010, dan salah satu upaya menahan laju pertumbuhan penduduk alami tersebut sebesar melalui pelaksanaan program KB.

Yang menjadi persoalan sebesar jumlah peserta KB baru yang direkrut setiap tahun walaupun mencapai target kuantitas tidak cukup meningkatkan jumlah dan persentase peserta KB aktif terhadap Total PUS. Persentase peserta KB aktif terhadap PUS tersebut sulit untuk ditingkatkan karena setiap tahunnya selalu terdapat peserta KB yang drop out atau menghentikan pemakaian dengan berbagai alasan; ingin anak pertama, ingin menambah jumlah anak, lupa menelan pil, lupa suntikan ulangan, lupa pakai kondom serta alasan logistik, sementara untuk mencapai peserta KB baru yang benar-benar baru semakin tidak mudah sejak awal reformasi (1997).

Tujuan mendapatkan peserta KB baru ini sebesar untuk dapat lebih lama mempertahankan tingkat kelangsungan (continuation rate) pemakaian alat atau menjalani metode tersebut. Usaha lain yang dilakukan sebesar melakukan pendekatan personal kepada keluarga dari rumah ke rumah dan tidak hanya dilakukan dalam satu kali kunjungan. Pendekatan ini harus sering dilakukan karena konsultasi yang matang harus dilakukan dengan menggunakan media Komunikasi, Informasi dan Edukasi (KIE-Kit) yang mampu meningkatkan kemudahan, kemurahan dan kenyamanan serta kecepatan pelayanan. Untuk pemakai kontrasepsi Pil, Suntik dan Kondom, pendekatan dilakukan dari segi pembinaan dan dukungan logistik yang efektif. 
Tim peneliti sepakat melanjutkan penelitian Model Interaksi Pengelola KB Lini Lapangan pada tahun 2012 dengan Pengelolaan Program Keluarga Berencana di DKI Jakarta pada tahun 2013. Pada penelitian tahun 2012 ditemukan banyak variabel yang mempengaruhi interaksi tim pengelola/pelaksana Program KB tingkat Kecamatan dan Kelurahan, antara lain pelaksanaan peran sebagai pengelola yang dipandang efektif jika diturunkan dari tingkat kecamatan ke tingkat kelurahan dimana lurah sebagai ketua tim pengelola /pelaksana program KB di tingkat kelurahan dengan mempertimbangkan jumlah populasi dan PUS dalam satu kelurahan di DKI Jakarta.

Kemudian ketersediaan penyuluh lapangan KB yang ditempatkan di kelurahan serta tim pelaksana KB kelurahan yang terdiri dari unsur pelaksana Komunikasi, Informasi dan Edukasi ke masyarakat seperti penyuluh KB, PKK, PPKB-RW dan kader lainnya, serta unsur pelaksana pelayanan medis kontrasepsi KB di dalam klinik (Puskesmas, klinik KB pemerintah maupun swasta) termasuk pelayanan di luar klinik yang dilengkapi dengan sarana pelayanan dan alat/obat kontrasepsi. Keseluruhan komponen tersebut saling berhubungan dalam mewujudkan keberhasilan program KB di DKI Jakarta.

\section{Tujuan Penelitian}

Adapun tujuan penelitian ini sebesar untuk memberikan masukan kepada Pemda DKI Jakarta tentang berbagai kegiatan prioritas yang perlu dilaksanakan dan tujuan khusus sebesar: (1) Memperoleh hasil analisis hubungan antar variabel penting dalam pengelolaan program KB di DKI Jakarta. (2) Merumuskan usulan kegiatan bagi penyusunan rencana strategis pengelolaan Program KB di DKI Jakarta (3) Hasil studi ini berupa rekomendasi yang perlu dipertimbangkan dan diimplementasikan di wilayah DKI Jakarta serta dipublikasikan melalui seminar, jurnal ilmiah berskala nasional maupun internasional.

\section{Landasan Teori}

Setelah dilaksanakan studi eksploratif dengan pendekatan kualitatif studi sekaligus mengenali berbagai variabel yang diduga saling berhubungan dan saling mempengaruhi pada model interaksi antar tim pengelola dan tim pelaksana program KB lini lapangan pada tahun 2012. Maka tahun 2013 ini dilanjutkan dengan penelitian dengan pendekatan kuantitatif tentang Pengelolaan Program Keluarga Berencana Nasional di DKI Jakarta

Model sebesar rencana, representasi, atau deskripsi yang menjelaskan suatu objek, sistem, atau konsep, yang seringkali berupa penyederhanaan atau idealisasi. Model, Prototipe, purwarupa, atau arketipe sebesar bentuk awal (contoh) atau standar ukuran dari sebuah entitas. Dalam bidang desain, sebuah prototipe dibuat sebelum dikembangkan atau justru dibuat khusus untuk pengembangan sebelum dibuat dalam skala sebenarnya atau sebelum diproduksi secara massal (Henslin, 2002).

Sosiologi sebagai ilmu pengetahuan mempunyai beberapa objek (Henslin, 2002). Objek material sosiologi sebesar kehidupan sosial, gejala-gejala dan proses hubungan antara manusia yang memengaruhi kesatuan manusia itu sendiri. Objek formal sosiologi lebih ditekankan pada manusia sebagai makhluk sosial atau masyarakat. Dengan demikian objek formal sosiologi sebesar hubungan manusia antara manusia serta proses yang timbul dari hubungan manusia di dalam masyarakat.

Hampir semua gejala sosial yang terjadi di desa maupun di kota baik individu ataupun kelompok, merupakan ruang kajian yang cocok bagi sosiologi, asalkan menggunakan prosedur ilmiah. Ruang lingkup kajian sosiologi lebih luas dari ilmu sosial lainnya. Hal ini karena ruang lingkup sosiologi mencakup semua interaksi sosial yang berlangsung antara individu dengan individu, individu dengan kelompok, serta kelompok dengan kelompok di lingkungan masyarakat. Interaksi sosial merupakan hubungan tersusun dalam bentuk tindakan berdasarkan norma dan nilai sosial yang berlaku dalam masyarakat. Kita dapat mengamati atau merasakan bahwa apabila sesuai dengan norma dan 
nilai dalam masyarakat, interaksi tersebut akan berlangsung dengan baik, begitu pula sebaliknya, manakala interaksi sosial yang dilakukan tidak sesuai dengan norma dan nilai dalam masyarakat, interaksi tersebut kurang berlangsung dengan baik.

Organisasi sebesar susunan yang dibentuk oleh orang-orang untuk mencapai suatu tujuan (Robbins, 2005). Sebuah organisasi dapat terbentuk karena dipengaruhi oleh beberapa aspek seperti penyatuan visi dan misi serta tujuan yang sama dengan perwujudan eksistensi sekelompok orang terhadap masyarakat. Karena sebuah organisasi yang baik sebesar organisasi yang dapat diakui keberadaannya oleh masyarakat yang ada disekitarnya, keberadaan ini berupa suatu kontribusi yang diberikan sebuah organisasi tersebut.

Partisipasi dapat diartikan sebagai keterlibatan mental, pikiran, dan emosi atau perasaan seseorang dalam situasi kelompok yang mendorong untuk memberikan sumbangan kepada kelompok demi tercapai tujuan dan tanggung jawab terhadap usaha yang dilakukan. Ada tiga buah unsur penting yang menurut Keith Davis (1962) memerlukan perhatian khusus dalam partisipasi.

Brian S. Graham (2008) mengatakan bahwa ada metode baru untuk mengidentifikasi interaksi sosial dengan menggunakan batasan kondisi yang berbeda. Metode tersebut memberikan estimasi yang konsisten dengan multi hubungan sosial berupa interaksi sosial dalam bentuk garis lurus (Manski, 1993). Ketika interaksi sosial tidak sejajar dengan perkiraan kondisi tetap dan pengukuran pengujian yang konsisten, interaksi sosial tidak akan ada walaupun menggunakan sampel yang besar. Stephen L.Ross (2006) mengatakan, bahwa kota dan sekitarnya (suburbs) menyediakan rumah, tempat bekerja, fasilitas lingkungan sosial dan pendidikan kepada banyak individu dan keluarga dalam suatu kesatuan, bahkan strata sosial yang terdiri dari berbagai ras, etnik dan kelompok ekonomi.

Penelitian menunjukkan bahwa dampak stratifikasi tersebut tidak ada hubungannya dengan penghasilan seseorang, kecuali melalui interaksi sosial dengan tetangga, teman sekolah, dan teman kantor. Seseorang membuat pilihan untuk bekerja sama dengan orang yang berbeda suku, kelompok dan agama dan bisa cocok satu sama lain. Suatu teori baru berdasar pada titik persimpangan konseptual antara teori pertukaran dan teori identitas (Brown L.D, 2006). Walaupun kedua teori memiliki penekanan yang berbeda ketika digunakan dalam topik-topik penelitian, kedua interaksi sosial tersebut mempelajari dan memahami banyak fenomena yang sama melalui kacamata yang berbeda. Pengamatan yang lebih dekat dari teori yang berbeda menunjukkan bahwa mereka dapat saling melengkapi dan bukan saling bersaing dalam pemahaman, perilaku, dan struktural konsekuensi kognitif dari interaksi sosial. Setelah eksplorasi independen dari sudut pandang teori masing-masing pada interaksi sosial, persamaan antara dua perspektif tersebut diambil dan teori terpadu yang baru diusulkan. Teori pertukaran identitas berfungsi untuk menggabungkan menjadi satu kerangka pemahaman mengenai interaksi sosial yang diberikan oleh kedua perspektif tersebut.

Lebih lanjut jika ingin memahami lebih dalam tentang Pengelolaan Program KB di DKI Jakarta yang dilaksanakan oleh Tim Pengelola, maka tim, menurut Robbins (2007) merupakan kelompok yang upaya-upaya individu di dalamnya menghasilkan suatu kinerja yang lebih besar daripada jumlah masukan-masukan individual. Organisasi selalu berharap pada sinergi para anggotanya, sehingga salah satu ciri organisasi modern sebesar tidak ada lagi orang yang bekerja sendiri melainkan bekerja sebagai tim. Tim yang mampu bersinegi tentu telah melalui proses sosial dan interaksi sosial seperti diuraikan diatas. Menurut Gary Yukl ( 2001) kata tim biasanya mengacu pada sebuah kelompok tugas yang kecil dimana para anggotanya memiliki tujuan yang sama, peran yang saling bergantung pada ketrampilan yang saling melengkapi.

Interaksi sosial tersebut pada umumnya dilakukan melalui komunikasi diantara anggota tim. Komunikasi menurut Dixon (1996) sebesar pengiriman dan pemahaman dari suatu yang berarti. Komunikasi yang baik terjadi jika pengirim dan penerima bisa saling memahami apakah melalui suara, bahasa yang dimengerti, bahasa tubuh (body langguage), tanda-tanda /simbol-simbol, bunyi- 
bunyian, atau melalui tulisan yang dikirim melalui media seperti telepon, e-mail, faxmile, dan sebagainya. Menurut Robbins ( 2007) fungsi komunikasi ada empat, yaitu: mengendalikan perilaku, memotivasi, mengungkapkan perasaan dan informasi. Komunikasi interpersonal atau komunikasi diantara dua atau lebih manusia.

Peranan komunikasi dalam kerangka interaksi sosial maupun dalam rangka kerjasama tim sebesar sangat penting dan sangat menentukan keberhasilan suatu tim dalam mencapai sasaran atau tujuan. Komunikasi menyampaikan informasi dalam perkembangan teknologi informasi dan komunikasi yang begitu cepat berubah. Seperti yang dikemukakan oleh James A. O'Brien (2005) bahwa teknologi telekomunikasi yang paling cepat berubah baik melalui komputer maupun melalui telepon seluler. Teknologi Informasi seperti komputer dan Alat-alat komunikasi tersebut begitu cepat diadopsi dan digunakan sebagian besar organisasi, kelompok, tim, keluarga dan individu. Dewasa ini dikenal tim virtual yang para anggotanya menggunakan internet, intranet, ekstranet, dan jaringan lainnya untuk berkomunikasi, berkoordinasi, dan bekerjasama satu sama lain dalam tugas atau proyek dan mereka dapat bekerja di geografis yang berbeda dan bahkan untuk organisasi yang berbeda (James A. O’Brien, 2005).

\section{METODE}

Dengan mengamati dan mendalami permasalah tersebut, maka tim peneliti sepakat melanjutkan penelitian model interaksi tim pengelola program KB di lini lapangan tahun 2012 lalu, dengan melakukan mini survey tentang Pengelolaan Program KB di DKI Jakarta sebagai usulan penelitian kuantitatif dengan harapan dapat memberikan rekomendasi pada penyusunan rencana strategis program KB di DKI Jakarta.

Lokasi Penelitian sebesar di Provinsi DKI Jakarta dengan lima Wilayah Kotamadya Administratif dan seluruh kecamatan. Cara pengambilan sampel sebesar dengan cara stratified random sampling dengan mengambil sampel seluruh Kecamatan yang ada, dengan responden sebanyak empat orang yang sangat kompeten terhadap pelaksanaan program KB di Kecamatan, yaitu PPLKB dan PKB ditambah responden Tim Pengelola KB Kecamatan meliputi Camat dan Kepala Puskesmas Kecamatan. Jika jumlah kecamatan sebanyak 44, maka responden sebanyak 176 orang, ditambah dengan masing-masing empat orang dari lima Kantor KB Wilayah Kotamadya dan dua orang dari Kantor BPMPKB Kabupaten Administrasi Kepulauan Seribu, sehingga jumlah responden sebanyak 198 orang.

\section{Rerangka Penelitian}

Adapun kerangka penelitian tersebut digambarkan dalam bentuk hubungan antar variable independen dengan variable dependen sebagai berikut;

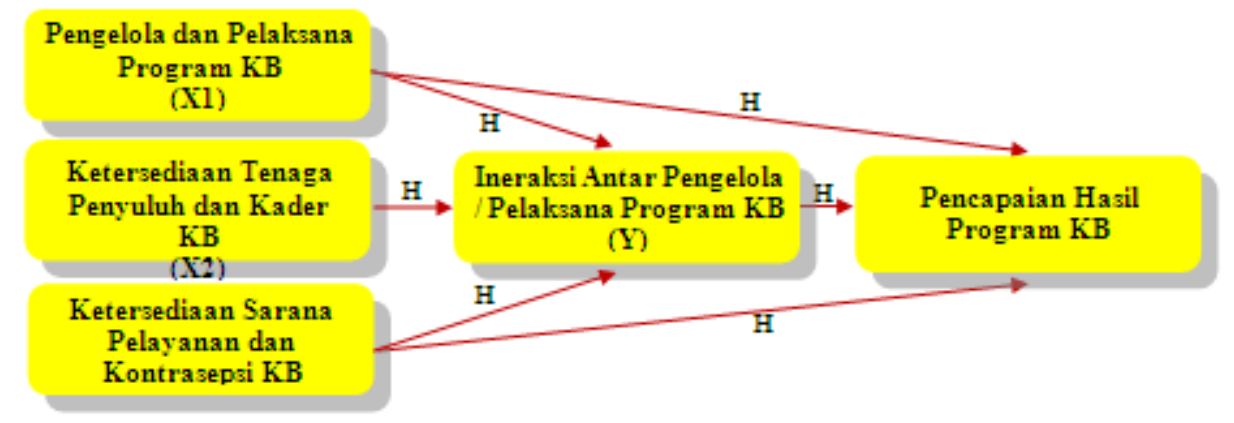

Gambar 1 Rerangka Penelitian Pengelolaan Program KB Nasional di DKI Jakarta 
Persamaan regresi sesuai model atau rerangka penelitian tersebut menunjukkan bahwa variavel dependen sebesar:

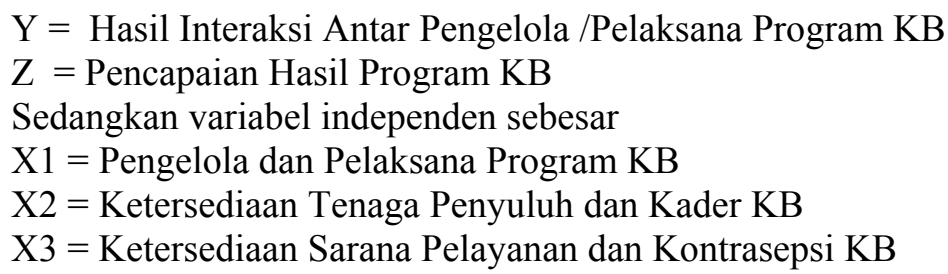

\section{Hipotesis}

Penelitian ini bertitik tolak dari hipotesis $\mathrm{Ho} \neq \mathrm{H} 1$. Ho dinyatakan bahwa tidak ada hubungan antar variabel, dan jika terbukti secara statistik menunjukkan adanya hubungan yang signifikan akan dinyatakan sebagai H1 diterima bahwa ada hubungan antar variabel yang lebih lanjut dianalisis makna hubungan tersebut dalam Pengelolaan Program KB di DKI Jakarta.

\section{HASIL DAN PEMBAHASAN}

Setelah merumuskan format variabel dan pertanyaan dalam kuesioner, maka dilakukan uji coba kuesioner untuk dijawab dan diisi oleh delapan orang responden pada dua kecamatan di wilayah yang berbeda untuk dilakukan pengujian. Hasil dari kuesioner responden diolah mengunakan program Lisrel, dimana langkah pertamanya sebesar menguji Reliability data dan Validitas data

Kemudian melaksanakan pengumpulan data melalui kuesioner yang disampaikan kepada 198 responden di DKI Jakarta. Mengolah data dengan menggunakan perangkat lunak PRELIS 2.80 (STUDENT) dan keluaran pengolahan tersebut menjadi bahan analisis Tim Peneliti untuk merumuskan hasil dan rekomendasi.

\section{Interpretasi Output Lisrel}

Data yang dikumpulkan melalui kuesioner dientri dan diolah dengan menggunakan SPSS yang selanjutnya dialakukan uji reabilitas, uji validitas dan uji normalitas.

\section{Uji normalitas}

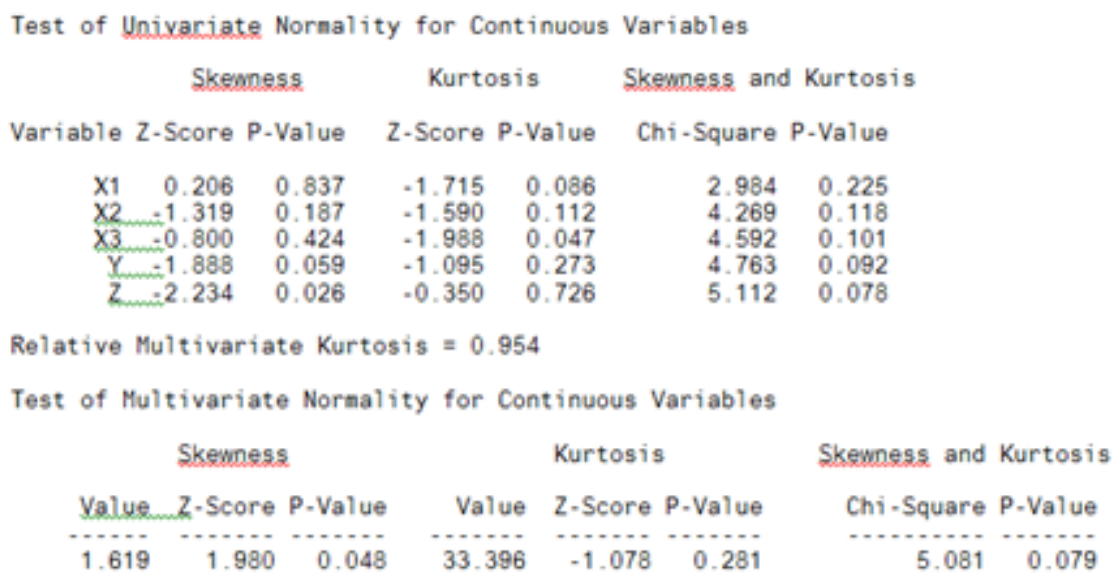

Data normal jika dilihat secara univariate maupun multivariate karena memiliki nilai probabilitas Skewness dan Kurtosis di atas 0.05. 


\section{Structural Equation}

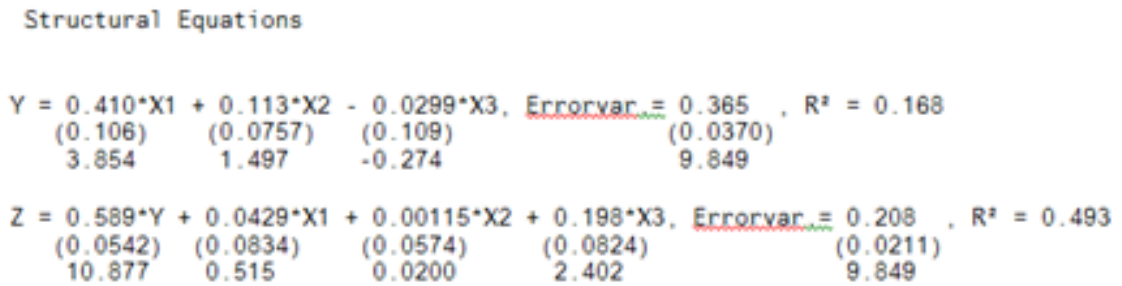

Persamaan regresi sesuai model atau rerangka penelitian tersebut menunjukkan bahwa variavel dependen sebesar:

$\mathrm{Y}=$ Hasil Interaksi Antar Pengelola /Pelaksana Program KB

$\mathrm{Z}=$ Pencapaian Hasil Program KB

Sedangkan variabel independen sebesar

X1 = Pengelola dan Pelaksana Program KB

X2 = Ketersediaan Tenaga Penyuluh dan Kader KB

X3 = Ketersediaan Sarana Pelayanan dan Kontrasepsi KB

\section{Persamaan I}

Hasil ini menunjukkan bahwa variabel $\mathrm{X}_{1}, \mathrm{X}_{2}$ dan $\mathrm{X}_{3}$ berpengaruh secara simultan terhadap variabel $\mathrm{Y}$ dengan nilai $\mathrm{R}$ square sebesar 0.168 . Artinya besarnya pengaruh variabel $\mathrm{X}_{1}, \mathrm{X}_{2}$ dan $\mathrm{X}_{3}$ terhadap variabel $\mathrm{Y}$ sebesar $16.8 \%$ dengan parameter estimate (error variance) sebesar 0.365 ; standard error variabel $\mathrm{X}_{1}$ sebesar 0.106 dan $t$-value variabel $\mathrm{X}_{1}$ sebesar 3.854; $\mathrm{X}_{2}$ sebesar 0.0757 dan $t$-value variabel $\mathrm{X}_{2}$ sebesar 1.497; dan $\mathrm{X}_{3}$ sebesar 0.109 dan t-value variabel $\mathrm{X}_{3}$ sebesar -0.274.

Matriks tersebut juga menunjukkan tingkat signifikansi pengaruh variabel $\mathrm{X}_{1}$ terhadap $\mathrm{Y}$, dari matriks tersebut dapat diketahui bahwa $t$-value $\left(\mathrm{t}_{\text {hitung }}\right)$ variabel $\mathrm{X}_{1}$ terhadap $\mathrm{Y}=3.854$ sedangkan $\mathrm{t}_{\text {tabel }}=$ 1.67. Dengan demikian diperoleh kesimpulan bahwa variabel $X_{1}$ berpengaruh secara signifikan terhadap variabel $Y$ karena nilai $t_{\text {hitung }}\left(\right.$ variabel $\left.X_{1}\right)>t_{\text {tabel }}$, yaitu $3.854>1.67$. Tingkat signifikansi pengaruh variabel $\mathrm{X}_{2}$ terhadap $\mathrm{Y}$, di mana dari matriks tersebut dapat diketahui bahwa $t$-value $\left(\mathrm{t}_{\text {hitung }}\right)$ variabel $\mathrm{X}_{2}$ terhadap $\mathrm{Y}=1.497$ sedangkan $\mathrm{t}_{\text {tabel }}=1.67$. Dengan demikian diperoleh kesimpulan bahwa variabel $\mathrm{X}_{2}$ tidak berpengaruh secara signifikan terhadap variabel $\mathrm{Y}$ karena nilai $\mathrm{t}_{\text {hitung }}\left(\right.$ variabel $\left.\mathrm{X}_{2}\right)<$ $t_{\text {tabel}}$, yaitu $1.497<1.67$. Tingkat signifikansi pengaruh variabel $\mathrm{X}_{3}$ terhadap $\mathrm{Y}$, di mana dari matriks tersebut dapat diketahui bahwa $t$-value $\left(\mathrm{t}_{\text {hitung }}\right.$ ) variabel $\mathrm{X}_{3}$ terhadap $\mathrm{Y}=-0.274$ sedangkan $\mathrm{t}_{\text {tabel }}=-1.67$. Dengan demikian diperoleh kesimpulan bahwa variabel $\mathrm{X}_{3}$ tidak berpengaruh secara signifikan terhadap variabel $\mathrm{Y}$ karena nilai $\mathrm{t}_{\text {hitung }}\left(\right.$ variabel $\left.\mathrm{X}_{3}\right)<\mathrm{t}_{\text {tabel }}$, yaitu $-0.274<-1.67$.

\section{Persamaan II}

Hasil ini menunjukkan bahwa variabel $\mathrm{Y}, \mathrm{X}_{1}, \mathrm{X}_{2}$ dan $\mathrm{X}_{3}$ berpengaruh secara simultan terhadap variabel $\mathrm{Z}$ dengan nilai $\mathrm{R}$ square sebesar 0.493 . Artinya besarnya pengaruh variabel $\mathrm{Y}, \mathrm{X}_{1}, \mathrm{X}_{2}$ dan $\mathrm{X}_{3}$ terhadap variabel $\mathrm{Z}$ sebesar $49.3 \%$ dengan parameter estimate (error variance) sebesar 0.446; standard error variabel $\mathrm{Y}$ sebesar 0.0542 dan t-value variabel $\mathrm{Y}$ sebesar $10.877 ; \mathrm{X}_{1}$ sebesar 0.0834 dan $t$-value variabel $\mathrm{X}_{1}$ sebesar $0.515 ; \mathrm{X}_{2}$ sebesar 0.0574 dan $t$-value variabel $\mathrm{X}_{2}$ sebesar 0.0200 ; dan $\mathrm{X}_{3}$ sebesar 0.0824 dan t-value variabel $\mathrm{X}_{3}$ sebesar 2.402 .

Matriks tersebut juga menunjukkan tingkat signifikansi pengaruh variabel $\mathrm{Y}$ terhadap $\mathrm{Z}$, dari matriks tersebut dapat diketahui bahwa $t$-value $\left(t_{\text {hitung }}\right)$ variabel $Y$ terhadap $Z=10.877$ sedangkan $t_{\text {tabel }}$ $=1.67$. Dengan demikian diperoleh kesimpulan bahwa variabel $\mathrm{Y}$ berpengaruh secara signifikan terhadap variabel $\mathrm{Z}$ karena nilai $\mathrm{t}_{\text {hitung }}($ variabel $\mathrm{Y})>\mathrm{t}_{\text {tabel}}$, yaitu $10.877>1.67$. Tingkat signifikansi pengaruh variabel $X_{1}$ terhadap $Z$, di mana dari matriks tersebut dapat diketahui bahwa $t$-value $\left(t_{\text {hitung }}\right.$ ) 
variabel $X_{1}$ terhadap $Z=0.515$ sedangkan $t_{\text {tabel }}=1.67$. Dengan demikian dapat disimpulkan bahwa variabel $\mathrm{X}_{1}$ tidak berpengaruh secara signifikan terhadap variabel $\mathrm{Z}$ karena nilai $\mathrm{t}_{\text {hitung }}\left(\right.$ variabel $\left.\mathrm{X}_{1}\right)<$ $\mathrm{t}_{\text {tabel}}$, yaitu $0.515<1.67$.

Tingkat signifikansi pengaruh variabel $\mathrm{X}_{2}$ terhadap $\mathrm{Z}$, dari matriks tersebut dapat diketahui bahwa t-value ( $\mathrm{t}_{\text {hitung }}$ ) variabel $\mathrm{X}_{2}$ terhadap $\mathrm{Z}=0.0200$ sedangkan $\mathrm{t}_{\text {tabel }}=1.67$. Dengan demikian dapat disimpulkan bahwa variabel $\mathrm{X}_{2}$ tidak berpengaruh secara signifikan terhadap variabel $\mathrm{Z}$ karena nilai $t_{\text {hitung }}$ (variabel $X_{2}$ ) $<t_{\text {tabel }}$, yaitu $0.0200<1.67$. Tingkat signifikansi pengaruh variabel $X_{3}$ terhadap $Z$, di mana dari matriks tersebut dapat diketahui bahwa $t$-value $\left(t_{\text {hitung }}\right)$ variabel $\mathrm{X}_{3}$ terhadap $\mathrm{Z}=2.402$ sedangkan $t_{\text {tabel }}=1.67$. Dengan demikian diperoleh kesimpulan bahwa variabel $X_{3}$ berpengaruh secara signifikan terhadap variabel $\mathrm{Z}$ karena nilai $\mathrm{t}_{\text {hitung }}\left(\right.$ variabel $\left.\mathrm{X}_{3}\right)>\mathrm{t}_{\text {tabel, }}$, yaitu $2.402>1.67$.

\section{Standardized Solution}

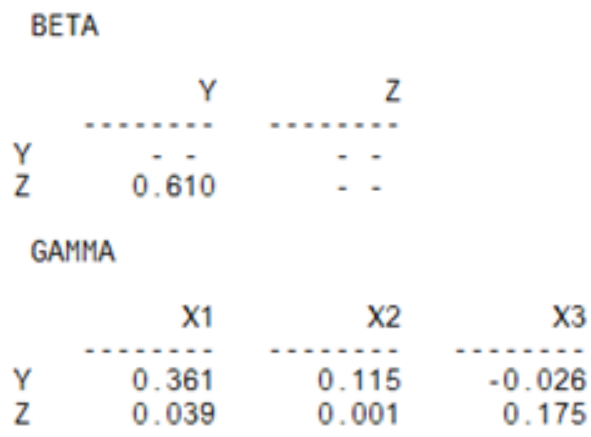

Berdasarkan matriks BETA dapat diketahui besar koefisien jalur antara variabel $\mathrm{Y}$ dan $\mathrm{Z}$ sebesar 0.610. Berdasarkan matriks GAMMA dapat diketahui besar koefisien jalur antara variabel $\mathrm{X}_{1}$ dan variabel $\mathrm{Y}$ sebesar 0.361 ; variabel $\mathrm{X}_{2}$ dan variabel $\mathrm{Y}$ sebesar 0.115 ; variabel $\mathrm{X}_{3}$ dan variabel $\mathrm{Y}$ sebesar -0.026. Sementara itu, besarnya koefisien jalur antara variabel $X_{1}$ dan variabel $Z$ secara langsung sebesar 0.039; variabel $\mathrm{X}_{2}$ dan variabel $\mathrm{Z}$ sebesar 0.001; variabel $\mathrm{X}_{3}$ dan variabel $\mathrm{Z}$ sebesar 0.175 .

\section{Standardized Total and Indirect Effects}

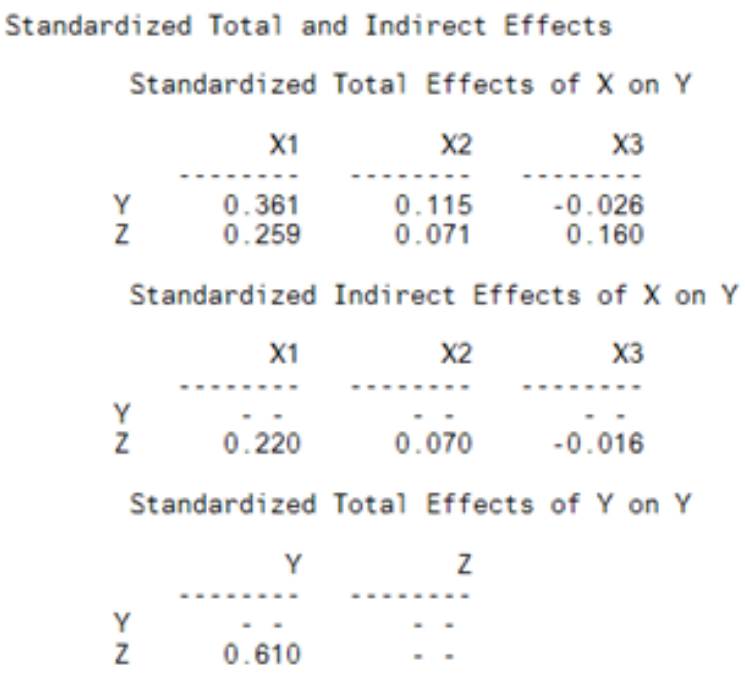


Berdasarkan matriks Standardized Indirect of X on Y dapat diketahui besarnya koefisien jalur antara variabel $\mathrm{X}_{1}$ dan variabel $\mathrm{Z}$ secara tidak langsung yaitu sebesar $0.220 ; \mathrm{X}_{2}$ dan variabel $\mathrm{Z}$ secara tidak langsung yaitu sebesar 0.070 ; dan $X_{3}$ dan variabel $Z$ secara tidak langsung yaitu sebesar -0.016 . Sementara, besarnya koefisien jalur antara variabel $X_{1}$ dan variabel $Z$ secara total sebesar sebesar $0.259 ; \mathrm{X}_{2}$ dan variabel $\mathrm{Z}$ secara total sebesar sebesar $0.071 ; \mathrm{X}_{3}$ dan variabel $\mathrm{Z}$ secara total sebesar sebesar 0.160 .

\section{PSI}

PSI

Note: This matrix is diagonal.

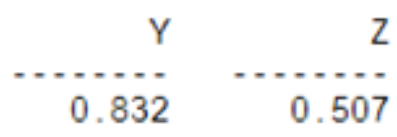

Berdasarkan matriks PSI dapat diketahui bahwa besarnya pengaruh dari variabel lain yang memengaruhi nilai variabel Y sebesar sebesar 0.832. Besarnya koefisien jalur dari variabel lain yang memengaruhi variabel $\mathrm{Y}\left(\varepsilon_{y}\right)=\sqrt{\mathbf{0 . 8 3 2}}=0.91$. Selain itu, diketahui pula bahwa besarnya pengaruh variabel lain yang memengaruhi nilai variabel $\mathrm{Z}$ sebesar sebesar 0.507 , sedangkan besarnya koefisien jalur dari variabel lain yang memengaruhi nilai variabel $\mathrm{Z}\left(\varepsilon_{z}\right)=\sqrt{0.507}=0.71$. Tabel berikut ini memberikan rangkuman hasil analisis jalur.

Tabel 1 Rekapitulasi Penelitian

\begin{tabular}{ccccc}
\hline \multirow{2}{*}{ Variabel } & Koefisien & \multicolumn{3}{c}{ Pengaruh } \\
\cline { 3 - 5 } & Jalur & Langsung & Tidak Langsung & Total \\
\hline $\mathrm{X}_{1}$ terhadap Y & 0.361 & 0.361 & - & 0.361 \\
$\mathrm{X}_{2}$ terhadap Y & 0.115 & 0.115 & - & 0.115 \\
$\mathrm{X}_{3}$ terhadap Y & -0.026 & -0.026 & - & -0.026 \\
$\mathrm{X}_{1}$ terhadap Z & 0.039 & 0.039 & 0.220 & 0.259 \\
$\mathrm{X}_{2}$ terhadap Z & 0.001 & 0.001 & 0.070 & 0.071 \\
$\mathrm{X}_{3}$ terhadap Z & 0.175 & 0.175 & -0.016 & 0.160 \\
Y terhadap Z & 0.610 & 0.610 & - & 0.610 \\
$\boldsymbol{s}_{y}$ & 0.91 & & & 0.84 \\
$\boldsymbol{s}_{z}$ & 0.71 & & & 0.95 \\
\hline
\end{tabular}

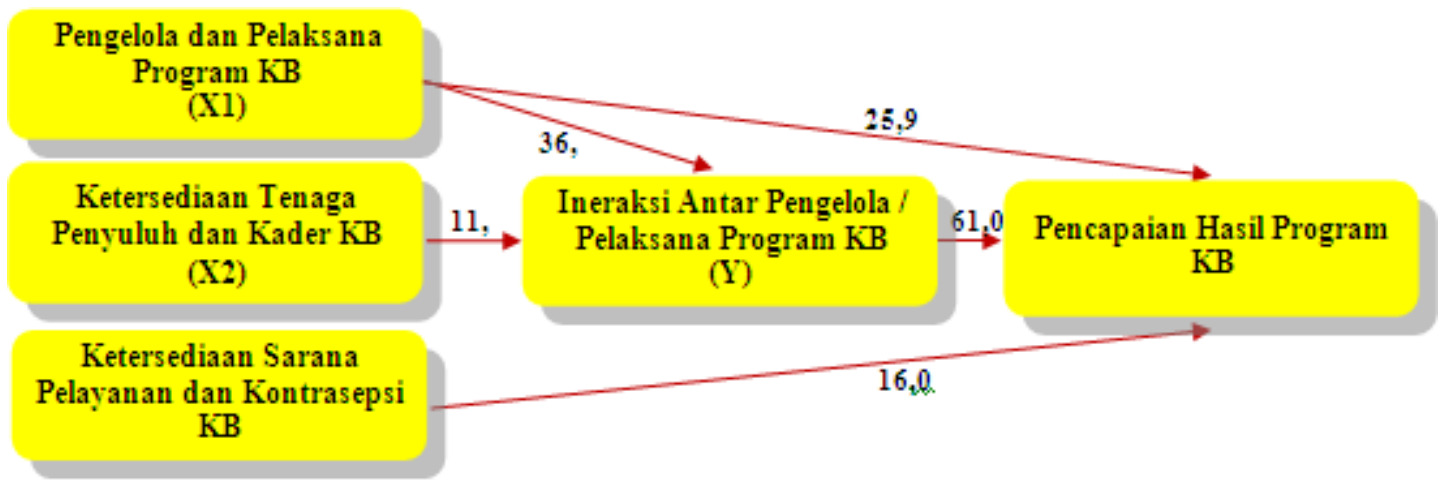

Gambar 2 Rekapitulasi Hasil Sumber: Hasil pengolahan peneliti (2013) 


\section{SIMPULAN}

Setelah menganalisis hasil pengolahan data kuantitatif persamaan regresi dengan interpretasi output LISREL dapat disimpulkan bahwa terdapat hubungan antara beberapa variabel indenden dengan variabel dependen secara simultan, sehingga HO yang menyatakan tidak ada hubungan variable independen dengan variable dependen dalam penelitian ini ditolak, dan $\mathrm{H} 1$ sebagai hipotesis alternative dapat diterima. Keberhasilan pencapaian program KB Nasional di DKI Jakarta sangat dipengaruhi oleh kualitas interaksi antar para Pengelola dan Pelaksana Program yang ada ditingkat Kecamatan dan Kelurahan dengan nilai R square sebesar 0.493 atau 49,3 persen, yang didukung oleh peran Pengelola/Pelaksana KB dan Ketersediaan sarana pelayanan KB.

Lebih lanjut berdasarkan analisis diketahui adanya pengaruh dalam hubungan secara simultan antara variabel Pelaksanaan Peran Pengelola/Pelaksana, Ketersediaan Tenaga Penyuluh dan Kader dan Ketersediaan Sarana Pelayanan KB terhadap Hasil Interaksi Antar Pengelola/Pelaksana KB (Y) hanya sebesar nilai $\mathrm{R}$ square sebesar 0.168 atau 16,8 persen. Setelah dikaji lebih mendalam maka Peran Pengelola/Pelaksana KB (variabel $\mathrm{X}_{1}$ ) terhadap Hasil Interaksi Antar Pengelola/Pelaksana (Y) berpengaruh secara signifikan terhadap variabel $Y$ karena nilai $t_{\text {hitung }}\left(\right.$ variabel $\left.X_{1}\right)>t_{\text {tabel }}$, yaitu $3.854>$ 1.67. Sedangkan ketersediaan tenaga penyuluh dan sarana pelayanan KB kurang berpengaruh terhadap Hasil Interaksi Pengelola/Pelaksana KB. Hal ini menekankan bahwa pelaksanaan peran Pengelola/Pelaksana KB sangat penting melalui proses interaksi yang lebih intensif diantara para Pengelola/Pelaksana Program KB Nasional di DKI Jakarta.

Kemudian hubungan antara semua variable secara simultan terhadap Keberhasilan Program KB Nasional di DKI Jakarta seperti yang dikemukakan diatas, bahwa diperoleh kesimpulan bahwa variabel Sarana Pelayanan dan Kontrasepsi $\mathrm{KB}\left(\mathrm{X}_{3}\right)$ yaitu Ketersedian berpengaruh secara signifikan terhadap variabel $Z$ (Keberhasilan Pelaksanaan Program KB) karena nilai $t_{\text {hitung }}$ (variabel $X_{3}$ ) $>t_{\text {tabel }}$, yaitu $2.402>1.67$

\section{Rekomendasi}

Berdasarkan analisis dan kesimpulan tersebut diatas, maka direkomendasikan kepada Gubernur DKI Jakarta bahwa perlu ditingkatkan segera peran pengelola/pelaksana program KB Nasional di DKI Jakarta melalui berbagai media interaksi yang telah ada seperti Rapat Koordinasi Perencanaan, Pelaksanaan dan Evaluasi Program KB secara periodik di tingkat Provinsi, Kotamadya dan Kecamatan dan dilaksanakan secara konsisten.

Kemudian perlu ditingkatkan rencana kegiatan Diklat KB yang telah lama ada namun selama 12 tahun belakangan menjadi kurang aktif untuk melatih semua pengelola dan pelaksana Program KB nasional di DKI Jakarta, agar mereka mampu dan mau melaksanakan fungsi dan peran mengelola dan melaksanakan programKB lebih intensif dimasa-masa mendatang.

Disarankan untuk melengkapi ketersediaan tenaga medis pelayan kontrasepsi seperti dokter dan bidan terlatih dalam memberikan pelayanan medis mengenai kontrasepsi pada setiap sarana pelayanan KB Pemerintah maupun Swasta di DKI Jakarta. Disarankan untuk melengkapi peralatan dan kontrasepsi pada setiap sarana pelayanan kontrasepsi pada Sarana Pelayanan Pemerintah dan Swasta di DKI Jakarta. 


\section{DAFTAR PUSTAKA}

Brown, LD. (2006). Memperkenalkan Teori Interaksi Sosial, Paper disajikan pada pertemuan tahunan American Association Sosiologi, Montreal Convention Center, Montreal, Quebec, Kanada

Davis, K. (1962). Human Relations at Work. New York, San Francisco, Toronto, London.

Dixon, T. (1996). Communication, Organization Performance. Norwood, New Jersey: Ablex Publishing.

Graham B. S. (2008). Identifying Social Interactions through Conditional Variance Restrictions, Econometrica, Econometric Society, 76(3), 643-660, 05.

Henslin, J. M. (2002). Essential of Sociology: A Down to Earth Approach, Fourth Edition. Boston.

Henslin, J. M. (2002). Sociological Theory. New York : Mc Graw-Hill.

O'Brien, J. A. (2006). Introduction to Information System /Pengantar Sistem Informasi. Jakarta: Salemba Empat.

Robbins, S. P., Coulter, M. (2005). Management ( $8^{\text {th }}$ Edition). New Jersey: Pearson Education.

Robbins, S. P., Judge, T. A. (2007). Orgaization Behavior (12 ${ }^{\text {th }}$ Edition). New Jersey: Pearson Education. 